\title{
PENGARUH SELEKSI DAN PELATIHAN TERHADAP PERSEPSI KINERJA PEGAWAI, DENGAN KOMPETENSI SEBAGAI VARIABEL INTERVENING (Studi Empirik Pada Inspektorat Jenderal Kementerian Agama)
}

\author{
Ali Ghozi, M.M. ${ }^{1}$ dan Darwanto, M.Ak. ${ }^{2}$ \\ ${ }^{1}$ Direktorat Jenderal Pendidikan Islam Kementerian Agama, \\ ${ }^{2}$ Inspektorat Jenderal Kementerian Agama \\ 19alighozi.99@gmail.com, ${ }^{2}$ wanto.aki@gmail.com,
}

\begin{abstract}
This study aims to verify and explain that Selection $\left(X_{1}\right)$ and Training $\left(X_{2}\right)$ has positive and significant influence to Perception of Employee Performance $\left(Y_{2}\right)$ mediated by Competency $\left(Y_{1}\right)$. Population in this study are employees at Inspectorate General of Ministry of Religion Affair. The sampel used in study are 136 respondents used sensus method. Data analysis was conducted by using Structural Equation Modeling (SEM) to analyze correlation between the independent variables (Selection $\left(X_{1}\right)$ and Training $\left(X_{2}\right)$ on the dependent variables (Perception of Employee Performance $\left(Y_{2}\right)$ ) with Competency $\left(Y_{1}\right)$ as a intervening variable. The data was processed using AMOS 21.0 (Analysis of Moment Structures). The SEM analysis result has fulfilled Goodness of Fit Index Criteria with coefficient Chi-Square $=36,078$, Probability=0,171, RMSEA=0,043, GFI=0,953, AGFI=0,912, $C M I N / d f=1,244, T L I=0,956$, and $C F I=0,972$. The result shows that selection has a positive and significant influence on the perception of employee performance (coefficient 0,65). Selection with competency as an intervening variable gives positive and significant influence on the perception of employee performance (coefficient 0,6878). Training has not a positive and significant influence on the perception of employee performance (coefficient -0,21). Training with competency as an intervening variable gives positive and significant influence on the perception of employee performance (coefficient 0,0798). Competency has a positive and significant influence on the perception of employee performance (coefficient 1,261).
\end{abstract}

Keywords: selection, training, competency, perception of employee performance

\section{LATAR BELAKANG}

Manajemen kepegawaian di lingkungan pemeritahan menjadi sorotan yang begitu serius sejak era reformasi digulirkan, karena pada dasarnya aparatur sipil negara (ASN) harus memberikan pelayanan yang sebaik-baiknya kepada masyarakat, dalam bingkai tata kelola pemerintahan yang baik (good governance), bebas dari korupsi. Undang-undang Nomor 5 Tahun 2014 Tentang Aparatur Sipil Negara menjadi tonggak reformasi manajemen kepegawaian dengan memberlakukan sistem merit, yakni pengelolaan ASN berdasarkan pada kualifikasi, kompetensi, dan kinerja secara adil dan wajar. Dengan sistem merit tersebut diatur seleksi dan promosi secara adil dan kompetitif, penerapan prinsip fairness, penggajian, reward dan punishment berbasis kinerja, standar integritas dan perilaku untuk kepentingan publik, dan manajemen sumber daya manusia secara efektif dan efisien.

Sumber Daya Manusia (SDM) merupakan salah satu faktor penting sebuah organisasi atau perusahaan apalagi pada sebuah 
manajemen (Darmawan, 2013: 2), sehingga kinerja pegawai dapat dijadikan salah satu tolak ukur keberhasilan organisasi. Kinerja pegawai (prestasi kerja) adalah hasil kerja secara kualitas dan kuantitas yang dicapai oleh seseorang karyawan dalam melaksanakan tugasnya sesuai dengan tanggung jawab yang diberikan kepadanya (Mangkunegara, 2000:67). Kinerja yang berjalan baik dalam sebuah organisasi dapat menentukan keberhasilan di dalam pencapaian tujuan visi dan misi dari organisasi itu sendiri. Dalam sektor pemerintahan, kinerja dapat diartikan sebagai suatu prestasi yang dicapai oleh aparatur sipil negara atau instansi pemerintah dalam melaksanakan tugas dan fungsinya.

Kinerja pegawai (individu) maupun kelompok merupakan kontribusi untuk meningkatkan kinerja suatu organisasi, sebab kinerja organisasi merupakan sekumpulan prestasi-prestasi yang diberikan oleh seluruh bagian yang terkait dengan aktivitas bisnis. Setiap organisasi pasti mengiginkan setiap pegawainya memiliki kinerja yang tinggi dalam bekerja, karena itu dibutuhkan pegawai yang memiliki kompetensi dalam menyelesaikan setiap pekerjaannya agar mendapatkan hasil yang baik. Oleh karena itu, Kompetensi merupakan karakteristik yang mendasari seseorang, yang memungkinkan dia memberikan kinerja yang unggul dalam memberikan pekerjaan (Shermon, 2004: 11).

Pelatihan diperlukan ketika karyawan mengalami ketimpangan pengetahuan dan keterampilan untuk melaksanakan tugas yang diemban (Hartoyo, 2003: 29), sehingga dengan pelatihan dapat meningkatkan kompetensi dan pada akhirnya pegawai dapat melaksanakan pekerjaan dengan baik untuk meningkatkan kinerjanya meningkat. Hal tersebut senada dengan yang diungkapkan Bernardin (2003: 164) bahwa Pelatihan didefinisikan sebagai setiap upaya untuk meningkatkan kinerja karyawan pada pekerjaan yang saat ini dipegang atau salah satu yang berhubungan dengan itu, hal ini biasanya berarti berakibat pada perubahan pengetahuan khusus, keterampilan, sikap, atau perilaku.

Selain pelatihan, proses penarikan penting karena kualitas sumberdaya manusia organisasi tergantung pada kualitas penarikannya (Handoko, 2000: 69), untuk itu harus dilaksanakan seleksi pegawai secara baik dan tepat agar diperoleh sumber daya manusia yang berkualitas. Seleksi merupakan proses identifikasi dan pemilihan orang dari sekelompok pelamar yang paling cocok atau yang paling memenuhi persyaratan untuk menduduki jabatan atau posisi tertentu suatu organisasi atau perusahaan. Seleksi adalah serangkaian aktivitas mencari dan memikat pelamar kerja dengan motivasi, kemampuan, keahlian, dan pengetahuan yang diperlukan guna menutupi kekurangan yang diidentifikasi dalam perencanaan kepegawaian (Simamora, 2004: 212)

Seleksi dan pelatihan merupakan faktor penting yang secara langsung menentukan tingkat kompetensi pegawai. Apabila pegawai yang direkrut tidak memiliki kompetensi yang memadai, maka akan kesulitan dalam menyelesaikan pekerjaannya. Lebih lanjut, untuk menyesuaikan dengan lingkungan organisasi dan kebutuhan kompetensi lanjutan sebagai tuntutan pekerjaan, maka pegawai tersebut membutuhkan berbagai macam pelatihan.

Beberapa peneliti telah menguji faktorfaktor yang dianggap mempengaruhi kinerja pegawai yang meliputi kompetensi, pelatihan, dan seleksi pegawai. Hasil penelitian Abidin dan Ismail (2010) dengan menggunakan sampel 1.136 pekerja yang baik eksekutif, manajer atau profesional dari tiga layanan sub-sektor, yaitu pendidikan, kesehatan dan teknologi informasi dan komunikasi di Selangor, Malaysia, menunjukkan bahwa kompetensi pegawai berpengaruh signifikan terhadap kinerjanya. Hasil penelitian tersebut senada dengan Shin dan Park (2009) yang 
menunjukkan bahwa kohesifitas pegawai dalam kelompok memiliki interaksi positif antara kompetensi terhadap kinerja, dengan kata lain kohesifitas kelompok yang diperkuat kompetensi akan mencapai kinerja yang lebih baik.

Farooq dan Khan (2011) meneliti dampak dari pelatihan dan umpan balik (feedback) pelatihan tersebut terhadap kinerja karyawan. Hasil penelitian menunjukkan bahwa pelatihan dapat berimplikasi pada meningkatnya kualitas dalam tim kerja untuk meningkatkan kinerja karyawan. Lebih lanjut, Sultana dkk (2012) meneliti dampak dari pelatihan terhadap kinerja pada karyawan di sektor telekomunikasi dengan hasil penelitian yang menunjukkan bahwa jika organisasi berinvestasi melalui pelatihan maka dapat meningkatkan kinerja karyawan serta kompetensi dan keterampilan. Selain itu, pelatihan dipandang sebagai sarana yang berguna untuk mengatasi perubahan seperti inovasi teknologi, persaingan pasar, penataan organisasi, dan yang paling penting itu memainkan peran kunci untuk meningkatkan kinerja karyawan.

Yullyanti (2009) menganilisis proses rekrutmen dan seleksi pada kinerja pegawai, dengan hasil penelitian, pertama, ditemukan bahwa seleksi signifian dipengaruhi oleh rekrutmen yang mencakup perencanaan dan waktu pelaksanaan rekrutmen, kedua, ditemukan bahwa kinerja dipengaruhi secara signifian oleh seleksi yang tercermin dari prosedur seleksi, peserta seleksi, dan pelaku seleksi, dan ketiga, rekrutmen memengaruhi secara tidak langsung terhadap kinerja melalui proses seleksi.

Aspek yang bisa dipotret dari kinerja pegawai Inspektorat Jenderal (itjen) Kementerian Agama adalah fakta empiris bahwa kontribusi besar yang menyokong pelaksanaan tugas fungsi itjen dalam beberapa tahun terakhir adalah tenaga segar baru yang diperoleh melalui seleksi online dengan berbagai tahapan yang menyertainya. Pada penghujung tahun 2014 Kementerian Agama melaksanakan perekrutan Calon Pegawai Negeri Sipil (CPNS) melalui beberapa tahapan yang dimulai dari perekrutan secara on-line, seleksi berkas, tes kompetensi dasar (TKD), dan tes kompetensi bidang (TKB).

Kinerja karyawan adalah Hasil kerja secara kualitas dan kuantitas yang dicapai oleh seseorang karyawan dalam melaksanakan tugasnya sesuai dengan tanggung jawab yang diberikan kepadanya (Mangkunegara,2009:9), sehingga kehadiran pegawai merupakan prasyarat agar karyawan tersebut dapat memberikan hasil kerja. Lebih lanjut, Mathis dan Jackson (2006:378) menyatakan beberapa indikator kinerja selain hasil kerja adalah kehadiran. Secara umum dari aspek kedisiplinan kehadiran pegawai terdapat perbedaan yang cukup mencolok antara pegawai sebelumnya dengan pegawai hasil seleksi tahun 2014. Pegawai yang aktif menjalankan tugas di kantor sebanyak 214 orang terdiri dari 124 pegawai lama dan 93 pegawai baru. Selain jumlah tersebut, terdapat fungsional auditor yang lebih banyak bertugas di lapangan/daerah sebanyak 179 pegawai.

Dari fenomena di atas, peneliti tertarik untuk menguji bagaimana kinerja pegawai dapat ditingkatkan. Kinerja pegawai dapat dipengaruhi oleh beberapa faktor, seperti motivasi, penempatan, pelayanan, pengalaman, kompetensi, seleksi, pelatihan, gaji, kebijakan pemerintah, dan lain-lain. Dalam penelitian ini, peneliti mengambil tiga hal penting yang berpengaruh pada kinerja pegawai, yaitu kompetensi, seleksi, dan pelatihan pada pegawai. Dalam kajian ini, kompetensi menjadi mediator bagi seleksi dan pelatihan terhadap kinerja pegawai. Oleh karena itu, peneliti mengambil judul "Pengaruh Seleksi Dan Pelatihan Terhadap Kinerja Pegawai, Dengan Kompetensi Sebagai Variabel Intervening (Studi Empirik Pada Inspektorat Jenderal Kementerian Agama). 


\section{TINJAUAN PUSTAKA}

\section{Kinerja}

Setiap organisasi menginginkan organisasinya terus dapat bersaing dan survive. Hal ini tentu saja harus didorong oleh peningkatan kinerja seluruh pegawai. Dimana terdapat peningkatan secara kuantitas maupun kualitas dari hasil maksimal yang telah dilakukan oleh pegawai terhadap pekerjaannya sesuai dengan job description yang sudah ditentukan oleh organisasi. Kinerja adalah prestasi yang dicapai seseorang dalam melaksanakan tugas dan pekerjaan yang diberikan kepadanya (Siswanto, 2009: 235). Kinerja juga merupakan hasil

\section{Kompetensi}

Kompetensi merupakan bagian dari kepribadian yang mendalam dan melekat pada setiap orang pada berbagai macam tugas dalam pekerjaannya. Palan (2003: 6) mendefinisikan komfetensi sebagai berikut: Competency refers to underlying behavioural characteristics that describe motives, traits, self-concept, values, knowledge or skills that superior performer brings to the workplace.

Kompetensi merefleksikan karakteristik seseorang dalam profesinya yang menunjukkan bahwa seseorang tersebut mampu menyelesaikan pekerjaan dengan pengetahuan dan keahlian yang dapat dipertanggungjawabkan serta bersikap

\section{Pelatihan}

Pelatihan ditujukan untuk meningkat kemampuan spesifik seseorang, biasanya dilakukan dalam jangka waktu yang relatif singkat untuk ilmu yang bersifat praktis. Training is defined as any attempt to improve employee performance on a currently held job or one related to it (Bernardin, 2003: 164), sehingga pelatihan dapat dilaksanakan sesuai dengan profesi pelaksanaan suatu pekerjaan baik bersifat fisik ataupun material dan non fisik non material (Cantika, 2005:114), sehingga kinerja juga dikenal sebagai karya.

Mangkunegara (2000:67) mengungkapkan bahwa faktor-faktor yang mempengaruhi pencapaian kinerja adalah: pengetahuan, keterampilan, kemampuan dan motivasi. Selanjutnya, kinerja juga harus bisa dinilai. Kontribusi hasil-hasil penilaian kinerja tersebut merupakan sesuatu yang bersifat bermanfaat bagi perencanaan kebijakan kebijakan organisasi (Sulistiyani dan Rosidah, 2009: 225).

sesuai dengan kode etik profesi yang berlaku. Rankin (2002) dalam Armstrong (2006: 159) mendeskripsikan kompetensi ke dalam dimensi keahlian (skills) dan perilaku (behaviours) dalam suatu organisasi yang mengekspektasikan stafnya untuk bekerja dan menjelaskan bahwa kompetensi dapat merepresentasikan suatu kinerja. Hal ini sejalan dengan Engel dan Marquardt dalam Shandler (1996: 235) dalam menggambarkan unsur kompetensi melalui keahlian dan prilaku yang mengungkapkan bahwa kompetensi terdiri dari sikap (attitude), keahlian (skill), dan pengetahuan (knowledge).

atau minat seseorang dalam rangka meingkatkan kinerjanya.

Pelatihan dilakukan untuk memenuhi tuntutan dalam persaingan global, dimana setiap orang sebaiknya memiliki keahlian dan kreativitas yang cukup dan semakin berkembang. Armstrong (2006: 575) mendefiniskan pelatihan yaitu: Training is the use of systematic and planned instruction activities to promote learning. 


\section{Seleksi}

Seleksi tenaga kerja diartikan sebagai suatu proses pemilihan beberapa orang dari kelompok orang-orang dengan preferensi tertentu (Wahyudi, 2002: 82). Seleksi merupakan suatu proses yang dibutuhkan suatu organisasi atau perusahaan untuk memutuskan pegawai yang tepat dari beberapa calon pegawai. Proses seleksi dilakukan setelah terlaksananya fungsi rekrutmen. Seleksi pegawai merupakan salah satu bagian yang penting dari keseluruhan proses manajemen sumber daya manusia dalam mencari pegawai.
Pentingnya seleksi mengakibatkan kegiatan tersebut harus dilakukan secara tepat dan benar untuk mendapatkan tenaga kerja yang dibutuhkan. Hal ini karena tuntutan dalam organisasi terhadap sekelompok pegawai yang memenuhi persyaratan. Seleksi adalah serangkaian aktivitas mencari dan memikat pelamar kerja dengan motivasi, kemampuan, keahlian, dan pengetahuan yang diperlukan guna menutupi kekurangan yang diidentifikasi dalam perencanaan kepegawaian (Simamora, 2004: 212).

\section{HIPOTESIS PENELITIAN}

\section{Seleksi Berpengaruh Positif dan Signifikan Terhadap Persepsi Kinerja Pegawai}

Hipotesis bahwa "Seleksi berpengaruh positif dan signifikan terhadap kinerja pegawai" akan diuji apakah hipotesis ini diterima atau ditolak. Di samping itu juga ingin menguji hipotesis lanjutan dari hipotesis pertama yang menyatakan bahwa "Seleksi berpengaruh positif dan signifikan terhadap kinerja pegawai, yang dimediasi oleh kompetensi". Dalam penelitian sebelumnya, kinerja dipengaruhi secara signifikan oleh seleksi (Yullyanti, 2009) dan proses seleksi berpengaruh positif dan signifikan terhadap kinerja (Pambagio dkk., 2013).

- $\mathrm{H}_{1}$ Seleksi berpengaruh positif dan signifikan terhadap kinerja pegawai.

- $\mathrm{H}_{2}$ Seleksi berpengaruh positif dan signifikan terhadap kinerja pegawai, yang dimediasi oleh kompetensi.

\section{Pelatihan Berpengaruh Positif dan Signifikan Terhadap Persepsi Kinerja Pegawai}

Hipotesis bahwa "Pelatihan berpengaruh positif dan signifikan terhadap kinerja pegawai" akan diuji apakah hipotesis ini diterima atau ditolak. Di samping itu juga ingin menguji hipotesis lanjutan dari hipotesis pertama yang menyatakan bahwa "Pelatihan berpengaruh positif dan signifikan terhadap kinerja pegawai, yang dimediasi oleh kompetensi”. Dalam penelitian sebelumnya, pelatihan berpengaruh positif terhadap kinerja pegawai (Elnaga dan Imran, 2013), pelatihan berpengaruh positif terhadap terhadap kinerja pegawai (Sultana, dkk., 2012), pelatihan dan pengembangan berpengaruh terhadap kinerja pegawai (Nassazi, 2013), dan pendidikan dan pelatihan berpengaruh langsung dan positif terhadap kompetensi (Alainati, dkk., 2009).

- $\mathrm{H}_{3}$ Pelatihan berpengaruh positif dan signifikan terhadap kinerja pegawai.

- $\mathrm{H}_{4}$ Pelatihan berpengaruh positif dan signifikan terhadap kinerja pegawai, yang dimediasi oleh kompetensi.

\section{Kompetensi Berpengaruh Positif dan Signifikan Terhadap Persepsi Kinerja Pegawai}

Hipotesis bahwa "Kompetensi berpengaruh positif dan signifikan terhadap kinerja pegawai" akan diuji apakah hipotesis ini diterima atau ditolak. Dalam penelitian sebelumnya, kompetensi berpengaruh positif dan signifikan terhadap kinerja (Pambagio dkk., 2013), kompetensi individual berpengaruh signifikan terhadap kinerja individual sedangkan kompetensi kolektif tidak berpengaruh 
signifikan/positif terhadap kinerja group (Shin dan Park, 2009), hubungan antara kompetensi dan kinerja tidak signifikan (Setyaningdyah, dkk., 2013), kompetensi pabrikasi tidak berpengaruh signifikan terhadap kinerja perusahaan (Dubey dan

\section{METODE PENELITIAN}

\section{Metode Analisis}

Metode analisis data menggunakan structual equation modeling (SEM). Metode ini digunakan dengan alasan latar belakang penelitian yang bersifat kausalitas (hubungan/pengaruh sebab akibat). Pemodelan SEM merupakan analisis yang cukup kompleks karena merupakan gabungan dari model regresi dengan path analysis untuk melihat pengaruh kausal, pengaruh langsung dan tidak langsung

\section{Populasi dan Sampel}

Teknik yang digunakan dalam pengambilan sampel pada penelitian ini adalah sensus, yaitu sampel dipilih adalah populasi itu sendiri. Populasi dari penelitian ini sebanyak 217 pegawai Inspektorat Jenderal Kementerian Agama yang sekaligus menjadi sampel penelitian ini. Proses pengumpulan data dilakukan dengan cara membagikan kuesioner kepada seluruh pegawai berjumlah 217 dikurangi pegawai

\section{Definisi dan Operasionalisasi Variabel}

Agar masing-masing variabel tersebut terdefinisi dengan jelas sesuai dengan tujuan penelitian, maka operasionalisasi
Ali, 2011), dan kesimpulan penelitian bahwa motivasi dan kompetensi berpengaruh tidak signifikan terhadap kinerja pegawai (Dhermawan, dkk., 2012).

- $\mathrm{H}_{5}$ Kompetensi berpengaruh positif dan signifikan terhadap kinerja pegawai.

(Bollen, 1989 dalam Sumarwan, et al. 2013). Melalui SEM, diuji secara bersamasama:

a. Model measurement : hubungan (nilai loading) antara indikator dengan konstruk laten (variabel laten).

b. Model struktural hubungan antara variabel eksogen dengan variabel endogen.

yang non aktif pada saat penyebaran kueioner berjumlah 36 dikarenakan tugas belajar, mutasi, diperbantukan pada instansi lain, dan lain-lain, sehingga kuesioner yang dibagikan sebanyak 181. Dari 181 kuesioner yang dibagikan terdapat 45 kuesioner yang tidak dikembalikan kepada peneliti, sehingga terdapat 136 kuesioner yang dapat dilakukan pengolahan data.

dan pengukurannya diuraikan sebagai berikut: 
Tabel 3

Operasionalisasi dan Pengukuran Variabel Penelitian

\begin{tabular}{|c|c|c|c|c|}
\hline Variabel & Definisi & Dimensi & Indikator & Skala \\
\hline \multirow[t]{2}{*}{ SELEKSI } & \multirow[t]{2}{*}{$\begin{array}{l}\text { Serangkaian aktivitas } \\
\text { mencari dan memikat } \\
\text { pelamar kerja dengan } \\
\text { motivasi, kemampuan, } \\
\text { keahlian, dan pengetahuan } \\
\text { yang diperlukan guna } \\
\text { menutupi kekurangan } \\
\text { yang diidentifikasi dalam } \\
\text { perencanaan kepegawaian } \\
\text { (Simamora, 2004: } 212 \text { ) }\end{array}$} & $\begin{array}{l}\text { Kualifikasi } \\
\text { Pelaksanaan } \\
\text { Seleksi }\end{array}$ & $\begin{array}{l}\text { - Keahlian } \\
\text { - Pengalaman } \\
\text { - Umur } \\
\text { - Jenis Kelamin } \\
\text { - Pendidikan } \\
\text { - Keadaan fisik } \\
\text { - Tampang } \\
\text { - Bakat } \\
\text { - Temperamen } \\
\text { - Karakter }\end{array}$ & \multirow[t]{2}{*}{$\begin{array}{c}\text { Rating } \\
\text { (1 s.d. 10) }\end{array}$} \\
\hline & & $\begin{array}{l}\text { Prosedur } \\
\text { Pelaksanaan } \\
\text { Seleksi }\end{array}$ & $\begin{array}{l}\text { - Tes tulis } \\
\text { - Psikotest } \\
\text { - Tes komputer } \\
\text { - Tes wawancara }\end{array}$ & \\
\hline \multirow[t]{2}{*}{ PELATIHAN } & \multirow[t]{2}{*}{$\begin{array}{l}\text { Defined as any attempt to } \\
\text { improve employee } \\
\text { performance on a } \\
\text { currently held job or one } \\
\text { related to it (Bernardin, } \\
\text { 2003: 164) }\end{array}$} & $\begin{array}{l}\text { Pelatihan } \\
\text { Teknis }\end{array}$ & $\begin{array}{l}\text { - Intensitas keikutsertaan } \\
\text { pelatihan teknis } \\
\text { - Penguasaan dan } \\
\text { penyampaian materi oleh } \\
\text { instruktur pelatihan } \\
\text { - Kegunaan isi materi } \\
\text { dengan tujuan pelatihan }\end{array}$ & \multirow[t]{2}{*}{$\begin{array}{c}\text { Rating } \\
\text { (1 s.d. } 10)\end{array}$} \\
\hline & & $\begin{array}{l}\text { Seminar, } \\
\text { lokakarya, } \\
\text { simposium }\end{array}$ & $\begin{array}{l}\text { - Intensitas keiktsertaan } \\
\text { seminar, lokakarya dan } \\
\text { simposium. } \\
\text { - Penguasaan dan } \\
\text { penyampaian materi oleh } \\
\text { instruktur pelatihan } \\
\text { - Kegunaan isi materi } \\
\text { dengan tujuan pelatihan }\end{array}$ & \\
\hline \multirow[t]{3}{*}{ KOMPETENSI } & \multirow[t]{3}{*}{$\begin{array}{l}\text { An underlying } \\
\text { characteristic of a person, } \\
\text { which enables him deliver } \\
\text { superior performance in } \\
\text { given a job (Shermon, } \\
\text { 2004: 11) }\end{array}$} & Pengetahuan & $\begin{array}{l}\text { - Mengetahui teori } \\
\text { pekerjaan } \\
\text { - Memahami prosedur } \\
\text { dalam bekerja } \\
\text { - Memahami aturan dalam } \\
\text { pekerjaan } \\
\text { - Mengetahui berbagai } \\
\text { bidang disiplin pekerjaan }\end{array}$ & \multirow[t]{3}{*}{$\begin{array}{c}\text { Rating } \\
\text { (1 s.d. } 10)\end{array}$} \\
\hline & & Keahlian & $\begin{array}{l}\text { - Mampu memecahkan } \\
\text { masalah } \\
\text { - Mampu berkomunikasi } \\
\text { dengan baik } \\
\text { - Mampu bekerja sama }\end{array}$ & \\
\hline & & Sikap & $\begin{array}{l}\text { - Tidak menyalahgunakan } \\
\text { wewenang } \\
\text { - Sikap objektif, jujur, } \\
\text { berani dan bertanggung } \\
\text { jawab } \\
\text { - Teliti dalam melaksanakan } \\
\text { prosedur } \\
\text { - Komunikasi yang efektif }\end{array}$ & \\
\hline $\begin{array}{l}\text { PERSEPSI } \\
\text { KINERJA } \\
\text { PEGAWAI }\end{array}$ & $\begin{array}{l}\text { Hasil kerja secara kualitas } \\
\text { dan kuantitas yang dicapai } \\
\text { oleh seseorang karyawan }\end{array}$ & Kualitas Kerja & $\begin{array}{l}\text { - Mengevaluasi pekerjaan } \\
\text { - Meningkatkan kualitas } \\
\text { pekerjaan }\end{array}$ & $\begin{array}{c}\text { Rating } \\
\text { (1 s.d. 10) }\end{array}$ \\
\hline
\end{tabular}




\begin{tabular}{llll}
\hline Variabel & Definisi & Dimensi & Indikator \\
\hline $\begin{array}{l}\text { dalam melaksanakan } \\
\text { tugasnya sesuai dengan } \\
\text { tanggung jawab yang } \\
\text { diberikan kepadanya } \\
\text { (Mangkunegara,2009:9) }\end{array}$ & Kuantitas Kerja & $\begin{array}{l}\text { - Waktu yang digunakan } \\
\text { dalam menyelesaikan } \\
\text { pekerjaan }\end{array}$ \\
\cline { 2 - 3 } & & $\begin{array}{l}\text { Jumlah kesalahan dalam } \\
\text { melaksanakan pekerjaan }\end{array}$ \\
\cline { 2 - 3 } & Tujuan & $\begin{array}{l}\text { Dapat bekerjasama dalam } \\
\text { tim }\end{array}$ \\
& Organisasi & $\begin{array}{l}\text { Pekerjaan sebagai dasar } \\
\text { bagi organisasi untuk } \\
\text { mencapai hasil akhir }\end{array}$ \\
\hline
\end{tabular}

\section{HASIL PENELITIAN DAN PEMBAHASAN \\ Pengujian Structural Equation Modeling (SEM)}

Gambar 1

Analisis Model Penelitian

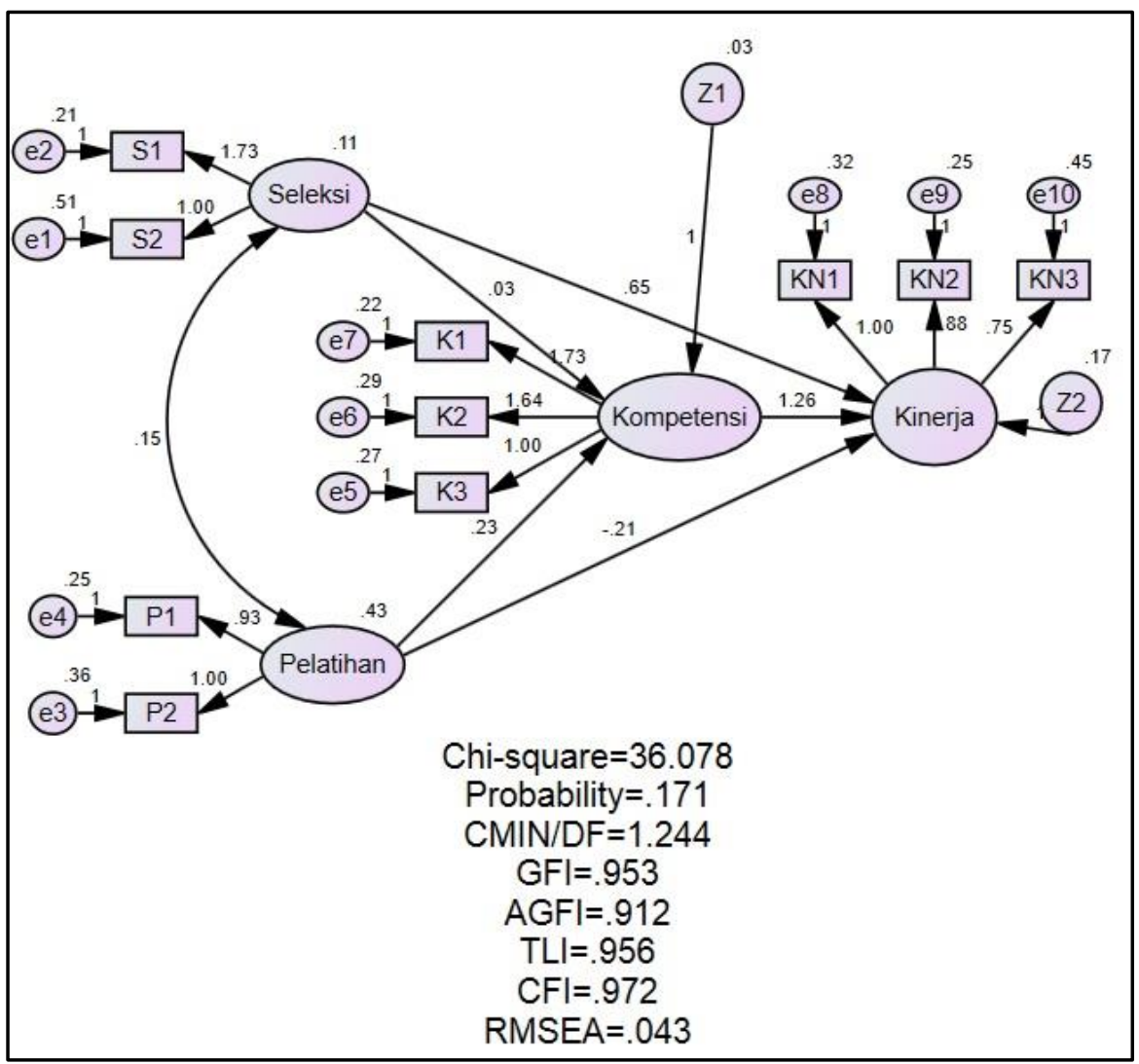

Berdasarkan kriteria pengujian Goodness Of Fit suatu model struktural, dengan bantuan program AMOS versi 21 dapat dibuatkan tabel pengukuran Goodness $O f$ Fit model penelitian sebagai berikut: 
Tabel 3

Hasil Pengujian Goodness of Fit

\begin{tabular}{|c|c|c|c|}
\hline $\begin{array}{c}\text { Goodness of Fit } \\
\text { Index }\end{array}$ & Cut-of Value & Hasil Model & Keterangan \\
\hline Chi-square $\left(\mathrm{X}^{2}\right)$ & & 36,078 & Baik \\
\hline Probability & $\geq 0,05$ & 0,171 & Baik \\
\hline RMSEA & $\leq 0,085$ & 0,043 & Baik \\
\hline$G F I$ & $\geq 0,90$ & 0,953 & Baik \\
\hline AGFI & $\geq 0,90$ & 0,912 & Baik \\
\hline CMIN/df & $\leq 2,00$ & 1,244 & Baik \\
\hline$T L I$ & $\geq 0,90$ & 0,956 & Baik \\
\hline$C F I$ & $\geq 0,95$ & 0,972 & Baik \\
\hline
\end{tabular}

Memperhatikan hasil tabel 3 di atas dengan membandingkan nilai Cut-of Value dengan nilai Hasil Model dari delapan kriteria pengujian Goodness of Fit model seluruh kriteria yang hasilnya sesuai standar yaitu

\section{Pengujian Hipotesis}

Tahapan berikutnya dalam analisis Structural Equation Modelling (SEM) adalah menguji hipotesis penelitian. Untuk menguji hipotesis penelitian, dangan

Tabel 4

Daftar Nilai Koefisien Pengaruh Seleksi, Pelatihan, dan Kompetensi Terhadap Persepsi Kinerja Pegawai

Regression Weights: (Group number 1 - Default model)

\begin{tabular}{|c|c|c|c|c|c|c|c|}
\hline & & & Estimate & S.E. & C.R. & $\mathrm{P}$ & Label \\
\hline Kompetensi & $<--$ & Seleksi & .026 & .154 & .168 & .866 & par_7 \\
\hline Kompetensi & $<---$ & Pelatihan & .227 & .088 & 2.565 & .010 & par_8 \\
\hline Kinerja & $<--$ & Kompetensi & 1.261 & .590 & 2.138 & .033 & par_9 \\
\hline Kinerja & $<--$ & Seleksi & .650 & .395 & 1.647 & .100 & par_10 \\
\hline Kinerja & $<--$ & Pelatihan & -.212 & .243 & -.875 & .382 & par_11 \\
\hline
\end{tabular}

Analisis pengaruh dilakukan untuk menganalisis kekuatan pengaruh antar konstruk baik pengaruh langsung, pengaruh tidak langsung, dan pengaruh total. Efek langsung (direct effect) tidak lain adalah koefisien dari semua garis koefisien dengan
Chi-square $=36,078 ;$ Probability $=0,171 ;$ RMSEA $=0,043 ;$ CMIN/df $=1,244 ; T L I=$ 0,956; dan $C F I=0,972$ sehingga hasil model dapat diterima dengan baik. Maka berdasarkan hasil model tersebut secara keseluruhan dianggap fit.

bantuan program AMOS versi 21 berikut ini disajikan tabel hasil analisis regresi dari variabel penelitian : 
Gambar 2

Pengaruh Antar Variabel Dalam Diagram Jalur

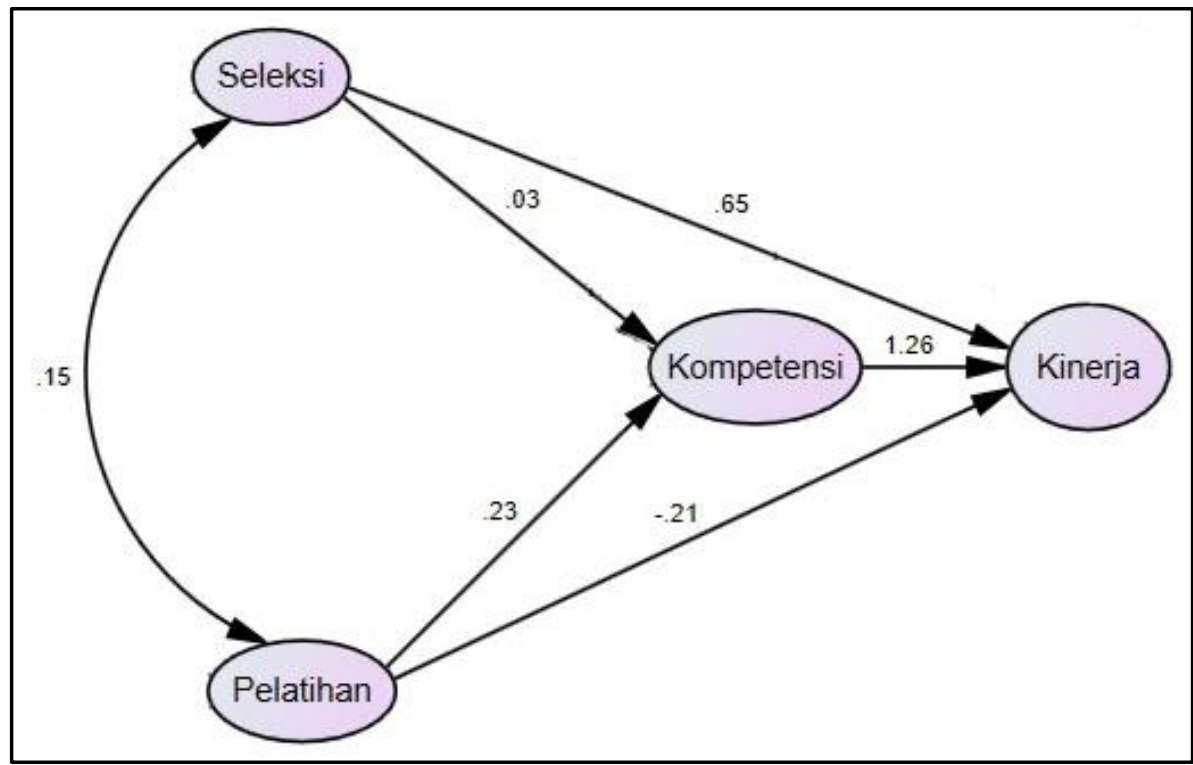

Dari Gambar 2 di atas maka dapat di hitung besarnya pengaruh langsung, pengaruh

tidak langsung, dan pengaruh total sebagai berikut:

Tabel 5

Pengujian Pengaruh Variabel Intervening

\begin{tabular}{|l|l|l|}
\hline Pengujian & Seleksi $\rightarrow$ Kinerja & Pelatihan $\rightarrow$ Kinerja \\
\hline Pengaruh Langsung & $=0,65$ & $=-0,21$ \\
\hline Pengaruh Tidak Langsung & $\begin{array}{l}=0,03 \times 1,26 \\
=0,0378\end{array}$ & $\begin{array}{l}=0,23 \times 1,26 \\
=0,2898\end{array}$ \\
\hline Pengaruh Total & $\begin{array}{l}=0,65+0,0378 \\
=0,6878\end{array}$ & $\begin{array}{l}=-0,21+0,2898 \\
=0,0798\end{array}$ \\
\hline Kesimpulan & $\begin{array}{l}\text { Pengaruh total }>\text { Pengaruh } \\
\text { langsung } \\
\text { Perlu intervening }\end{array}$ & $\begin{array}{l}\text { Pengaruh total }>\text { Pengaruh } \\
\text { langsung } \\
\text { Perlu intervening }\end{array}$ \\
\hline
\end{tabular}

$H_{1}$ Seleksi berpengaruh positif dan signifikan terhadap kinerja pegawai.

Berdasarkan informasi yang disajikan dalam tabel 4.5 diketahui nilai pengaruh variabel Seleksi $\left(\mathrm{X}_{1}\right)$ terhadap Kinerja $\left(\mathrm{Y}_{2}\right)$ bersifat positif dan signifikan dengan nilai probability $(P)$ sebesar 0,100 serta nilai koefisien (Estimate) sebesar 0,650. Dengan demikian maka $\mathrm{H}_{1}$ diterima, artinya variabel Seleksi $\left(\mathrm{X}_{1}\right)$ berpengaruh positif dan signifikan terhadap Kinerja $\left(\mathrm{Y}_{2}\right)$ terbukti secara empiris. Hasil ini sejalan dan memperkuat temuan peneliti-peneliti sebelumnya. Yullyanti

(2009) menjelaskan bahwa kinerja dipengaruhi secara signifikan oleh seleksi yang tercermin dari prosedur seleksi, peserta seleksi, dan pelaku seleksi. Begitu juga dengan Pambagio dkk (2013) yang menjelaskan bahwa proses seleksi berpengaruh positif dan signifikan terhadap kinerja. Semakin baik proses pelaksanaan seleksi maka dapat meningkatkan kinerja pegawai, kualifikasi yang sesuai dengan 
kebutuhan organisasi sebagai hasil dari prosedur seleksi yang baik akan memberikan output pegawai yang memiliki kinerja yang tinggi.

\section{$\mathrm{H}_{2}$ Seleksi berpengaruh positif dan signifikan terhadap kinerja pegawai, yang}

dimediasi oleh kompetensi.

Berdasarkan informasi yang disajikan dalam tabel 4.6 diketahui bahwa pengaruh total Seleksi terhadap Kinerja Pegawai $(0,6878)$ lebih besar dari pengaruh langsung $(0,65)$. Dengan demikian $\mathrm{H}_{2}$ diterima, artinya variabel Seleksi $\left(\mathrm{X}_{1}\right)$ berpengaruh positif dan signifikan terhadap kinerja pegawai $\left(\mathrm{Y}_{2}\right)$, yang dimediasi oleh Kompetensi $\left(\mathrm{Y}_{1}\right)$ terbukti secara empiris. Hasil ini sejalan dan memperkuat temuan peneliti-peneliti sebelumnya. Proses penarikan penting karena kualitas sumberdaya manusia organisasi tergantung pada kualitas penarikannya (Handoko, 2000: 69), untuk itu pelaksanaan seleksi pegawai secara baik dan tepat dapat diperoleh sumber daya manusia yang berkualitas, memiliki kompetensi. Lebih lanjut kompetensi dapat meningkatkan kinerja organisasi.

\section{$\mathrm{H}_{3}$ Pelatihan berpengaruh positif dan signifikan terhadap kinerja pegawai.}

Berdasarkan informasi yang disajikan dalam tabel 4.5 diketahui nilai pengaruh variabel Pelatihan $\left(\mathrm{X}_{1}\right)$ terhadap Kinerja $\left(\mathrm{Y}_{2}\right)$ tidak bersifat positif dan tidak signifikan dengan nilai probability $(P)$ sebesar 0,382 serta nilai koefisien (Estimate) sebesar -0,212. Dengan demikian maka $\mathrm{H}_{3}$ ditolak, artinya variabel Pelatihan $\left(\mathrm{X}_{2}\right)$ berpengaruh positif dan signifikan terhadap Kinerja $\left(\mathrm{Y}_{2}\right)$ tidak terbukti secara empiris. Hasil penelitian ini tidak sejalan dengan penelitian-penelitian sebelumnya seperti Nassazi (2013), Sulthana dkk (2012), Hermanto (2005), dan Elanaga dan Imran (2013) yang menjelaskan bahwa pelatihan berpengaruh terhadap kinerja. Dari hasil empiris dapat dijelaskan bahwa hasil daripada pelatihan tidak dapat langsung berpengaruh terhadap peningkatan kinerja, karena pelatihan merupakan simulasi terhadap kerja, bukan pekerjaan yang sebenarnya sehingga pegawai perlu mempraktikkan hasil untuk pelatihan tersebut untuk mendapatkan kompetensi kerja yang sebenarnya dibutuhkan untuk peningkatan kinerja. Kompetensi kerja sebagaimana dimaksud tercapai apabila melalui proses percobaan hasil pelatihan untuk mendapatkan keahlian dalam teknis pekerjaan, pengetahuan tentang pekerjaan dan prosedurnya, serta sikap untuk beradaptasi menyesuaikan pekerjaan yang berbeda-beda. Pelatihan diperlukan ketika karyawan mengalami ketimpangan pengetahuan dan keterampilan untuk melaksanakan tugas yang diemban (Hartoyo, 2003: 29), sehingga pelatihan dibutuhkan ketika terjadi ketimpangan kompetensi pada pegawai maka perlu variabel intervening untuk meningkatkan pelatihan terhadap kinerja.

\section{$H_{4}$ Pelatihan berpengaruh positif dan signifikan terhadap kinerja pegawai, yang dimediasi oleh kompetensi.}

Berdasarkan informasi yang disajikan dalam tabel 4.6 diketahui bahwa pengaruh total Pelatihan terhadap Kinerja Pegawai $(0,0798)$ lebih besar dari pengaruh langsung $(-0,21)$. Dengan demikian $\mathrm{H}_{4}$ diterima, artinya variabel Pelatihan $\left(\mathrm{X}_{2}\right)$ berpengaruh positif dan signifikan terhadap kinerja pegawai $\left(\mathrm{Y}_{2}\right)$, yang dimediasi oleh Kompetensi $\left(\mathrm{Y}_{1}\right)$ terbukti secara empiris. Hasil ini sejalan dengan penelitian Alainati dkk (2009) dan Hartoyo (2003) bahwa pelatihan berpengaruh positif terhadap kompetensi. Selanjutnya kompetensi 
berpengaruh signifikan terhadap kinerja sebagaimana hasil penelitian Shin dan Park (2009).

\section{H5 Kompetensi berpengaruh positif dan signifikan terhadap kinerja pegawai.}

Berdasarkan informasi yang disajikan dalam tabel 4.5 diketahui nilai pengaruh variabel Kompetensi $\left(\mathrm{Y}_{1}\right)$ terhadap Kinerja $\left(\mathrm{Y}_{2}\right)$ bersifat positif dan signifikan dengan nilai probability $(P)$ sebesar 0,033 serta nilai koefisien (Estimate) sebesar 1,261. Dengan demikian maka $\mathrm{H}_{5}$ diterima, artinya variabel Kompetensi $\left(\mathrm{Y}_{1}\right)$ berpengaruh positif dan signifikan terhadap Kinerja $\left(\mathrm{Y}_{2}\right)$ terbukti secara empiris. Hasil ini sejalan dan memperkuat temuan peneliti-peneliti sebelumnya seperti

\section{SIMPULAN, SARAN, DAN KETERBATASAN}

Berdasarkan hasil analisis, diperoleh kesimpulan bahwa:

1. Seleksi berpengaruh positif dan signifikan meningkatkan Persepsi Kinerja.

2. Seleksi berpengaruh positif dan signifikan meningkatkan Persepsi Kinerja Pegawai yang dimediasi oleh Kompetensi.
Dhermawan dkk (2012), Pambagio dkk (2013), dan Shin dan Park (2009), namun berbeda dengan hasil penelitian Dubey dan Ali (2011), Setyaningdyah dkk (2011) yang menjelaskan bahwa kompetensi tidak berpengaruh secara signifikan terhadap kinerja. Shermon (2004: 11) menjelaskan bahwa Kompetensi merupakan suatu karakteristik yang mendasari seseorang, yang memungkinkan dia memberikan kinerja yang unggul dalam memberikan pekerjaan.

\section{Saran yang diajukan berdasarkan hasil penelitian ini adalah:}

1. Agar model teoritis dan empiris pengaruh pelatihan terhadap kinerja pegawai, terutama pelatihan teknis dan seminar, lokakarya, dan simposium dapat lebih ditingkatkan lagi sehingga persepsi kinerja pegawai akan meningkat.
3. Pelatihan tidak berpengaruh positif dan signifikan meningkatkan Persepsi Kinerja Pegawai.

4. Pelatihan berpengaruh positif dan signifikan meningkatkan Persepsi Kinerja Pegawai yang dimediasi oleh.

5. Kompetensi berpengaruh positif dan signifikan meningkatkan Persepsi Kinerja Pegawai.

2. Agar model hubungan antara seleksi dan pelatihan dengan persepsi kinerja pegawai yang dimediasi oleh kompetensi, ditunjukkan dengan semangat reformasi birokrasi, inovasi, dan keteladanan.

\section{Keterbatasan dalam penelitian ini antara lain:}

1. Penelitian ini hanya meneliti pada Inspektorat Jenderal Kementerian Agama, maka untuk penelitian berikutnya diharapkan dapat meningkatkan ruang lingkup penelitian pada instansi Kementerian Agama atau dengan membandingkan Inspektorat atar Kementerian/Lembaga.
2. Variabel yang digunakan dalam penelitian ini hanya mencakup variabel seleksi, pelatihan dan kompetensi dalam kaitanya dengan persepsi kinerja pegawai, maka untuk peneliti berikutnya dapat menambahkan variabel-variabel lain seperti pengalaman, pendidikan, dan kepemimpinan yang dapat meningkatkan persepsi kinerja pegawai. 


\section{DAFTAR PUSTAKA}

Alainati, S., AlShawi, S.N., Al-Karaghouli, W., 2009. The Effect of Education and Training on Competenc. European and Mediterranean Conference on Information System 2010, Abu Dhabi UAE, 12-13 April.

Arikunto, Suharsimi. Prosedur Penelitian (Suatu Pendekatan Praktik), Edisi Revisi VI. Jakarta: Penerbit Rineka Cipta, 2006.

Armstrong, Michael. A Handbook of Human Resource Management Practice. London and Philadelphia: Kogan Page Limited, 2006.

Asngari, 1984. Persepsi Direktur Penyuluhan Tingkat Karesidenan dan Kepala Penyuluh Pertanian terhadap Peranan dan Fungsi Lembaga Penyuluh Pertanian di Negara bagian Texas Amerika Serikat. Media Peternakan Vol 9 No. 2 Fakultas Peternakan. Bogor: Institut Pertanian Bogor.

Bernardin, H. John. Human Resource Management: An Experiental Approach. McGraw-Hill/Irwin, 2003.

Cantika, Yuli. Manajemen Sumber Daya Manusia. Malang: Penerbit Universitas Muhammadiyah, 2005.

Darmawan, Didit. Prinsip-prinsip Perilaku Organisasi. Surabaya: Pena Semesta, 2013.

Dessler, Gary., Manajemen Sumber Daya Manusia (Edisi Kesepuluh Jilid I), Jakarta: PT. Indeks, 2011.

Dhermawan, Anak Agung Ngurah Bagus., I Gde Adnyana Sudibya, I Wayan Mudiartha Utama. Pengaruh Motivasi, Lingkungan Kerja, Kompetensi, dan Kompensasi terhadap Kepuasan Kerja dan Kinerja Pegawai di Lingkungan Kantor Dinas Pekerjaan Umum Provinsi Bali. Jurnal Manajemen,
Strategi Bisnis dan Kewirausahaan, Vol. 6, No. 2, Agustus 2012.

Djaali., Pudji Muljono. Pengukuran Dalam Bidang Pendidikan. Jakarta: Grasindo, 2007.

Dubey, Rameshwar., Sadia Samar Ali. Study on Effect of Functional Competency on Performance of Indian Manufacturing Sector, International Journal of Eng Business Managament, Vol 3, No. 3, 1-15, 2011.

Elnaga, Amir., Amen Imran. The Effect of Training on Employee Performance, Ueropean Journal of Business and Management, Vol 5, No. 4, 2013.

Farooq, Mubashar, Muhamamd Aslam Khan. Impact of Training and Feedback on Employee Performance. Far East Journal of Psychology and Business, Vol. 5 No. 1 October 2011, p. 23-33, 2011.

Handoko, T Hani. Manajemen Personalia dan Sumber Daya Manusia (Edisi Kedua). Yogyakarta: BPFE, 2000..

Hartoyo, 2003. Pengaruh Pengalaman dan Pelatihan Terhadap Kompetensi Auditor pada Inspektorat Jenderal Departemen Kehakiman Hak Asasi Manusia RI [Tesis]. Universitas Indonesia.

Hasibuan, Malayu S.P. Manajemen Sumber Daya Manusia. Jakarta: PT. Bumi Aksara, 2004.

Hermanto, 2005. Analisis Pengaruh Pelatihan, Pendidikan dan Pembinaan Karyawan terhadap Kinerja Pegawai Kantor Sekretariat Kabupaten Sorong, Jurnal Aplikasi Manajemen, Volume 3, Nomor 2, Agustus

Ismail, R., Syahida Z.A., 2010. Impact of workers' competence on their performance in the Malaysian private service sector. BEH - 
Business and Economic Horizons, Volume 2 Issue 2 July 2010 pp. 2536.

Istijanto. Aplikasi Praktis Riset Pemasaran (Plus 36 Topik Riset Pemasaran Siap Terap). Jakarta: PT. Gramedia pustaka Utama, 2005.

Kleiman, Lawrence S. Human Resource Management. St. Paul USA: West Publishing Company, 1997

LAN dan BPKP, 2000. Akuntabilitas dan Good Governance. Modul 1.

Latan, Hengky. Model Persamaan Struktural: Teori dan Implementasi AMOS 21.0. Bandung: Penerbit Alfabeta, 2013.

Mahsun, Mohammad. Pengukuran Kinerja Sektor Publik. Yogyakarta: BPFE Yogyakarta, 2006.

Mangkunegara, Anwar Prabu. Evaluasi Kinerja SDM. Bandung: PT. Refika Aditama, 2009.

Mangkunegara, Anwar. Manajemen Sumber Daya Manusia. Bandung: PT. Remaja Rosdakarya, 2000.

Manullang, M. 2001. Manajemen Personalia (Edisi 3). BPFE, Yogyakarta.

Mathis, Robert L., dan John H. Jackson. Human Resource Management Manajemen Sumber Daya Manusia, edisi 10. Jakarta: Salemba Empat, 2006.

Nassazi, A., 2013. Effects of Training on Employee Performance. University of Applied Sciences, Uganda.

Noe, Raymond A., John R. Hollenbeck, Barry Gerhart, Patrick M. Wright, Human Resource Management, Jakarta: Salemba Empat, 2010.

Pambagio, Nindrijo Sunu., Hamidah Nayati Utami, dan Gunawan Eko N. 2013. Pengaruh Proses Rekrutmen, Proses Seleksi, dan Kompetensi Karyawan Terhadap Kinerja Karyawan (Studi pada Karyawan Bagian Tata Usaha dan Keuangan $P G$ Kebon Agung Malang). Universitas Brawijaya, Malang.
Rakhmat, Jalaludin, 1992. Psikologi komunikasi. Bandung: PT. Remaja Rosdakarya.

Robbins, S.P., 2006. Perilaku Organisasi, Jilid I, (Edisi ke-10 terjemahan), PT. Gramedia, Jakarta.

Santoso, Singgih. Konsep Dasar dan Aplikasi SEM dengan AMOS 22. Jakarta: PT. Elex Media komputindo, 2014.

Setyaningdyah, Endang., Umar Nimran, Kertahadi, Armanu Thoyib., The Effect of Human Resource Competence, Organisational Commitment and Transactional Leadership on Work Discipline, Job Satisfaction and Employee's Performance, International Journal of Contemporary in Business, Agustus 2013, Vol. 5, No. 4.

Shermon, Ganesh. 2004. Competency Based HRM (A Strategic Resource For Competency Mapping, Assessment And Developing Centres). McGraw-Hill, Delhi.

Shin, Soo-Young. Won-Woo Park., Moderating Effects of Group Cohesiveness in Competency Performance Relationships: A Multi-Level Study. Journal of Behavioral Studies in Business, Volume 1 - July, 2009.

Silap, Meyvi. Bertha Mundung. Yance Tawas. 2013. Pengaruh Proses Rekrutmen Terhadap Kinerja Karyawan Pada PT. PLN (Persero) Sektor Pembangkitan Minahasa. Jurnal Manajemen dan Bisnis. Vol 1, No 1 (2013).

Simamora, Henry. Manajemen Sumber Daya Manusia. Yogyakarta: STIE YKPN, 2001.

Simamora, Henry. Manajemen Sumber Daya Manusia (Edisi 3). Yogyakarta: Aditama Media, 2004.

Siswanto, HB. Pengantar Manajemen, Cetakan Kelima. Jakarta: Bumi Aksara, 2009. 
Stoner, James A.F., R. Edward Freeman, Daniel R. Gilbert JR., Manajemen, Jakarta: PT Indeks, 1996.

Sugiyono, 2009, Metode Penelitian Bisnis (Pendekatan Kuantitatif, Kualitatif \& R\&D), Cet. Ke-13,CV. Alfabeta, Bandung.

Sulistiyani, Ambar Teguh dan Rosidah. Manajemen Sumber Daya Manusia, Edisi Kedua, Cetakan Pertama. Yogyakarta: Graha Ilmu, 2009.

Suliyanto. Ekonometrika Terapan: Teori dan Aplikasi dengan SPSS. Yogyakarta: Penerbit ANDI, 2011.

Sultana, Afshan., Sobia Irum., Kamran Ahmed., Nasir Mehmood., Impact Of Training On Employee Performance: A Study Of Telecommunication Sector In Pakistan. Interdisciplinary Journal Of Contemporary Research In Business, October 2012, Vol 4, No 6, p. 646-661.

Sumarwan, Ujang, Herien Puspitawati, Agustinus Hariadi, Mochammad Mukti Ali, Muhammad Gazali, Sri Hartono, Tara Farina. 2013. Riset
Pemasaran dan Konsumen. Bogor: IPB Press.

Supranto, J. 2000. Statistik (Teori dan Aplikasi). Penerbit Erlangga. Jakarta.

Supranto, J. 2003. Metode Riset. PT. Asdi Mahasatya. Jakarta.

Undang-undang Nomor 5 Tahun 2014 Tentang Aparatur Sipil Negara.

Vathanophas, Vichita. Jintawee Thaingam. 2007. Competency Requirements for Effective Job Performance in The Thai Public Sector. Contemporary Management Research, Pages 45-70, Vol.3, No.1, March 2007.

Wahyudi, Bambang. Manajemen Sumber Daya Manusia. Bandung: Sulita, 2002.

Yullyanti, Ellyta., Analisis Proses rekrutmen dan seleksi pada Kinerja Pegawai, Bisnis \& Birokrasi, Jurnal Ilmu Administrasi dan Organisasi, Sept-Des 2009, h. 131-139, Volume 16, Nomor 3. 